\title{
PENGEMBANGAN KOMPOSIT PANEL AKUSTIK BERBAHAN DASAR BIJI DAN KULIT KAPUK RANDU UNTUK MENINGKATKAN KOEFISIEN ABSORBSI BAHAN
}

\author{
Sahara*, Amirin Kusmiran \\ Program Studi Fisika \\ Fakultas Sains dan Teknologi UIN Alauddin Makassar \\ J1. Sultan Alauddin No. 63, Kabupaten Gowa, Sulawesi Selatan. 92113 \\ "E-mail: sahara.syamsuddin@uin-alauddin.ac.id
}

\begin{abstract}
Abstrak: Cangkang dan biji Ceiba pentandra berpotensi menjadi sampah organik jika sampah tersebut tidak dikelola dengan baik. Dampak negatif dari cangkang dan biji Ceiba pentandra merugikan lingkungan yaitu pencemaran air dan udara. Masalah ini dapat diatasi dengan mengolah sampah menjadi material yang bernilai ekonomis yaitu panel akustik dari material alam. Selain itu, penggunaan panel akustik untuk mengurangi polusi udara dari gelombang suara. Pembuatan bahan baku tersebut dilakukan dengan teknik hand lay-up dengan menggunakan polimer poliester sebagai matriks dan cangkang dan biji sebagai serat. Bahan baku pabrikan telah dikeringkan selama 10 jam untuk mendapatkan pemadatan panel akustik yang optimal. Untuk mengetahui koefisien absorpsi panel akustik dilakukan pengukuran kebisingan dari panel akustik berbahan cangkang, biji kasar dan halus Ceiba pentandra, baik tanpa aluminium foil maupun dengan aluminium foil. Pengaruh jarak terhadap penyerapan suara dari berbagai sampel juga dilakukan. Hasil penelitian menunjukkan bahwa koefisien serap tertinggi pada sampel dengan biji Ceiba petandra adalah 0,356 dengan aluminium foil sedangkan tanpa aluminium foil adalah 0,255 , koefisien serap tertinggi pada sampel dengan kulit Ceiba pentandra adalah 0,435 dengan aluminium foil sedangkan tanpa aluminium foil adalah 0,35 . dan koefisien serap tertinggi pada sampel dengan biji Ceiba pentandra adalah 0,427 dengan aluminium foil sedangkan tanpa aluminium foil adalah 0,272. Dengan demikian, penambahan aluminium foil dapat meningkatkan koefisien penyerapan panel akustik.
\end{abstract}

Kata Kunci: alumunium foil, cangkang dan biji Ceiba pentandra, polimer poliester, teknik hand lay-up

\section{PENDAHULUAN}

$\mathbf{K}$ ebisingan merupakan salah satu polusi yang dapat menyebabkan gangguan kesehatan, seperti darah tinggi, dan gangguan jantung(Münzel et al., 2014;Aluko menerus, dan spontan. Kebisingan dapat terjadi secara alami maupun buatan, seperti bunyi yang dihasilkan oleh gunung meletus dan mesin-mesin industri dengan intensitas yang melebihi $80 \mathrm{~dB}$. Namun, intensitas tersebut dapat dikurangi dengan menggunakan bahan yang dapat menyerap bunyi sehingga intensitas bunyi yang terdengar dapat diredam. Kualitas dari bahan penyerap bunyi ditunjukkan dengan nilai koefisien absorbsi 
baik pada material sintetik (Ali et al., 2018) maupun alami (Xiang et al., 2013; Yahya et al., 2017; Purnawati et al., 2018).

Penggunaan material alami terus dikembangkan sebagai pengganti material sintetik yang tidak ramah lingkungan untuk digunakan pada berbagai aplikasi di dunia industri, seperti di bidang otomotif, sebagaimana dinyatakan oleh Kusmiran et al. (2019). Panel akustik berbahan dasar kapuk randu terus dikembangkan, dan belum dimanfaatkan secara optimal karena hanya memanfaatkan serat kapuk randu. Sedangkan biji dan kulit kapuk randu belum dimanfaatkan untuk pembuatan panel komposit, padahal biji dan kulit mempunyai kemampuan tahan terhadap kondisi lembab dengan sifat mekanik (Kumar et al., 2018) lebih baik dibandingkan dengan serat kapuk randu. Kelebihan ini dapat dipertimbangkan untuk digunakan untuk pembuatan komposit panel akustik. Selain itu, karakteristik kapuk randu, khususnya serat, telah dilakukan pengujian baik sifat fisik maupun sifat mekanik, seperti menggunakan analysis FTIR, XRD, thermogravimetrik, dan tensile test (Kumar et al., 2018; Sekar et al., 2019). Karakteristik sifat kimia pada serat alami ditentukan dari tiga faktor yakni selulosa, hemiselulosa, dan lignin. Perbandingan komposisi kimia serat kapuk randu dengan serat alami lainnya diperlihatkan pada Tabel 1. Tabel tersebut memberikan informasi mengenai selulosa, hemiselulosa, lignin, densitas, dan kelembapan yang terdapat pada serat alami.

Tabel 1. Perbandingan serat kapuk randu dengan serat alami lainnya

\begin{tabular}{|c|c|c|c|c|c|c|c|}
\hline Penguat & $\begin{array}{c}\text { Selulosa } \\
(\mathrm{wt} \%)\end{array}$ & $\begin{array}{l}\text { Hemiselulosa } \\
(\mathrm{wt} \%)\end{array}$ & $\begin{array}{c}\text { Lignin } \\
(\mathrm{wt} \%)\end{array}$ & $\begin{array}{l}\text { Waks } \\
(\mathrm{wt} \%)\end{array}$ & $\begin{array}{c}\text { Kelembapan } \\
(\%)\end{array}$ & $\begin{array}{c}\text { Densitas } \\
\left(\mathrm{kg} / \mathrm{m}^{3}\right)\end{array}$ & $\begin{array}{c}\text { Ash } \\
(\mathrm{wt} \%)\end{array}$ \\
\hline Serat kapuk & 60.90 & 17.53 & 23.50 & 0.38 & 7.46 & 682 & 1.05 \\
\hline $\begin{array}{l}\text { Acacia } \\
\text { leucophloea }\end{array}$ & 68.09 & 13.60 & 17.73 & 0.55 & 8.83 & 1385 & 0.08 \\
\hline $\begin{array}{l}\text { Dichrostachys } \\
\text { cinerea }\end{array}$ & 72.40 & 13.08 & 16.89 & 0.57 & 9.82 & 1240 & 0.08 \\
\hline Acacia Arabica & 68.10 & 9.36 & 16.86 & 0.49 & - & 1028 & 3.97 \\
\hline Azadirachta indica & 68.42 & 13.72 & 13.58 & 0.43 & - & 740 & - \\
\hline Greweiatilifolia & 62.80 & 21,20 & 14.90 & - & 2.3 & - & - \\
\hline Cordia dichotoma & 59.70 & 23.60 & 14.70 & - & - & - & - \\
\hline Acacia planifrons & 73.10 & 9.41 & 12.04 & 0.57 & 8.21 & 660 & 4.06 \\
\hline Psopis juliflora & 61.65 & 16.14 & 17.11 & 0.61 & 9.48 & 580 & 5.20 \\
\hline
\end{tabular}

Sumber: Kumar et al., 2018

Pengembangan yang dilakukan untuk mendapatkan komposit panel akustik dengan koefisien absorbsi optimal dan tahan terhadap kelembapan adalah mengkombinasikan komposisi biji, kulit, dan serat kapuk randu, sehingga dapat digunakan untuk berbagai aplikasi seperti dinding akustik, dan material komposit lainnya.

Pada penelitian ini menggunakan material biji dan kulit, sebagai penguat atau fiber dan resin polyester sebagai matriks. Kombinasi kedua material tersebut menghasilkan material panel akustik berpenguat bahan alam. Hasil penelitian ini menjadi dasar untuk dikembangkan untuk menghasilkan produk-produk yang dapat meredam gelombang bunyi salah satunya polyethylene terephthalate (PET). 


\section{METODE PENELITIAN}

Pengembangan panel akustik dengan bahan serat, kulit, dan biji kapuk randu dilakukan di Laboratorium Fisika Dasar UIN Alauddin Makassar. Material tersebut sebagai matriks panel akustik yang berfungsi sebagai peredam gelombang akustik atau suara sedangkan perekat menggunakan resin polyester. Adapun tahapan penelitian yang digunakan sebelum mendapatkan kompaksi panel akustik yakni studi literatur, preparasi sampel (Gambar 1) dan alat, pembuatan papan akustik, dan analisis data.

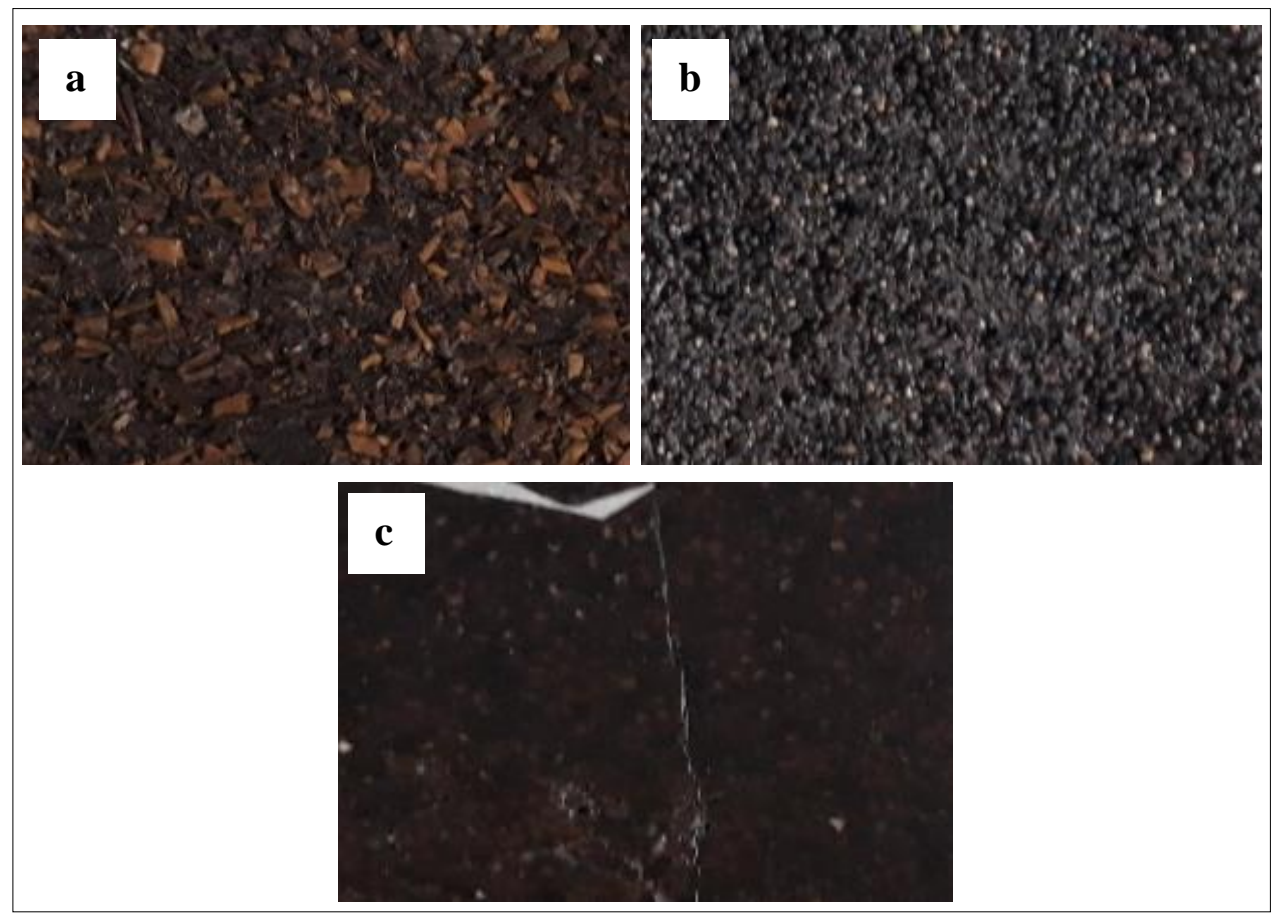

Gambar 2. Sampel uji a) kulit kapuk randu; b) biji halus kapuk randu; dan c) biji kasar kapuk randu.

Sampel dibagi menjadi tiga kategori, yakni sampel kulit kapuk randu, biji kasar dan halus kapuk randu. Semua sampel tersebut dimasukan ke dalam cetakan sampel. Di dalam cetakan sampel tersebut, sampel tersebut ditambahkan resin polyester sambil diaduk. Hal ini dilakukan dengan tujuan untuk mendapatkan sampel uji yang homogen. Fabrikasi komposit panel akustik (Gambar 1) dilakukan dengan teknik hand layup (Kusmiran et al., 2020) dengan tujuan untuk mendapatkan kompaksi sampel sebelum pengujian koefisien absorbsi dilakukan. Kompaksi panel akustik tersebut dilakukan dengan cara komposit panel akustik dikeringkan selama 10 jam. Pengujian komposit panel akustik dilakukan seperti pada Gambar 2.

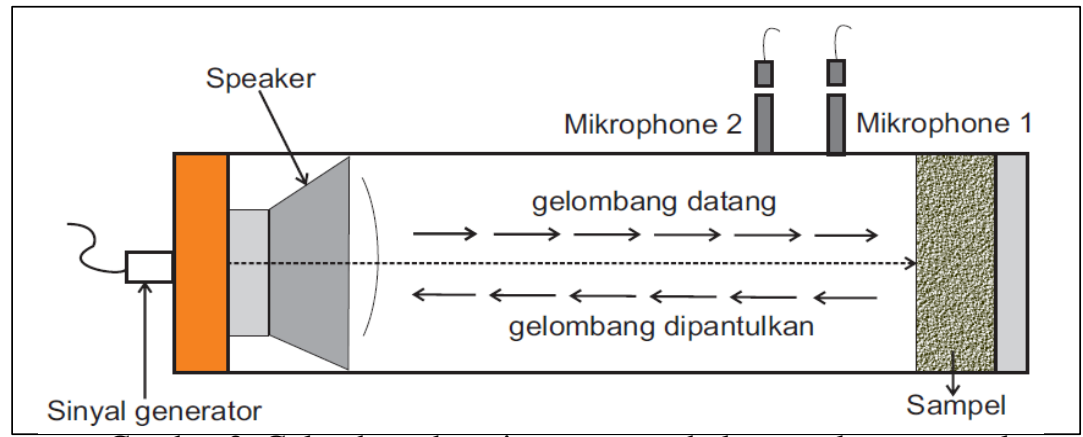

Gambar 2. Gelombang bunyi saat menumbuk permukaan sampel 
Sumber bunyi yang pada penelitian dengan frekuensi sebesar $250 \mathrm{~Hz}, 500 \mathrm{~Hz}, 1000$ $\mathrm{Hz}, 2000 \mathrm{~Hz}$, dan $4000 \mathrm{~Hz}$. Rentang frekuensi tersebut termasuk merupakan variasi dari panjang gelombang tinggi sampai dengan panjang gelombang rendah. Hal ini bertujuan untuk mengetahui kemampuan tingkat absorbsi komposit panel akustik yang telah dirancang. Besar koefisien absorbsi komposit panel akustik dihitung dengan menggunakan persamaan:

$$
\alpha=\frac{\ln I_{0}-\ln I}{x}
$$

dimana $\alpha$ adalah koefisien absorbsi, $I_{0}$ adalah intensitas awal bunyi dalam $\mathrm{dB}, I$ adalah intensitas bunyi yang diukur, dan $x$ adalah jarak ke sumber bunyi. Berdasarkan persamaan 1, jarak komposit panel akustik ke sumber bunyi menjadi indikator penelitian pada penelitian ini dimana jarak yang digunakan yaitu $10 \mathrm{~cm}, 20 \mathrm{~cm}, 30 \mathrm{~cm}$, dan $40 \mathrm{~cm}$. Selain itu, penelitian ini juga memodifikasi sampel uji dengan menggunakan alumunium foil. Pengukuran Intensitas bunyi pada masing-masing sampel uji dilakukan sebanyak tiga sehingga rata-rata intensitas bunyi dari setiap sampel digunakan sebagai intensitas untuk menghitung koefisien absorbsi berdasarkan Persamaan 1. Pengukuran intensitas dilakukan sebanyak tiga kali pada setiap sampel uji untuk menentukan intensitas awal $I_{o}$, dan intensitas akhir $I$. dimana intensitas awal, $I_{o}$, diperlihatkan pada Tabel 1 .

Tabel 2. Intensitas awal atau referensi pada kulit, biji halus dan bulat kapuk randu

\begin{tabular}{ccccc}
\hline Jarak $(\mathbf{c m})$ & $\mathbf{f}(\mathbf{H z})$ & I_rata-rata $(\mathbf{d B})$ & SD & I (dB) \\
\hline \multirow{3}{*}{10} & 250 & 89.200 & 0.100 & 89.300 \\
& 500 & 89.767 & 0.058 & 89.824 \\
& 1000 & 91.533 & 0.306 & 91.839 \\
2000 & 89.800 & 0.608 & 90.408 \\
& 4000 & 90.300 & 0.100 & 90.400 \\
20 & 250 & 89.400 & 0.100 & 89.500 \\
& 500 & 85.100 & 0.000 & 85.100 \\
& 1000 & 90.633 & 0.058 & 90.691 \\
& 2000 & 90.500 & 0.000 & 90.500 \\
30 & 4000 & 91.000 & 0.000 & 91.000 \\
& 250 & 89.900 & 0.100 & 90.000 \\
& 500 & 90.600 & 0.000 & 90.600 \\
& 1000 & 91.000 & 0.000 & 91.000 \\
40 & 2000 & 90.800 & 0.000 & 90.800 \\
& 4000 & 90.400 & 0.000 & 90.400 \\
& 250 & 88.500 & 0.000 & 88.500 \\
& 500 & 77.200 & 0.000 & 77.200 \\
& 1000 & 91.100 & 0.000 & 91.100 \\
& 2000 & 91.300 & 0.219 & 91.519 \\
& 4000 & 90.900 & 0.000 & 90.900 \\
\hline
\end{tabular}




\section{HASIL DAN PEMBAHASAN}

Intensitas merupakan phenomena gelombang yang diteruskan atau melewati material panel akustik dengan memanfaatkan biji dan kulit kapuk randu. Selain itu dilakukan pengembangan panel akustik dengan penambahan aluminium foil. Penambahan aluminium foil ini dapat meningkatkan koefisien absorbsi panel akustik sebagaimana diperlihatkan pada Gambar 2.
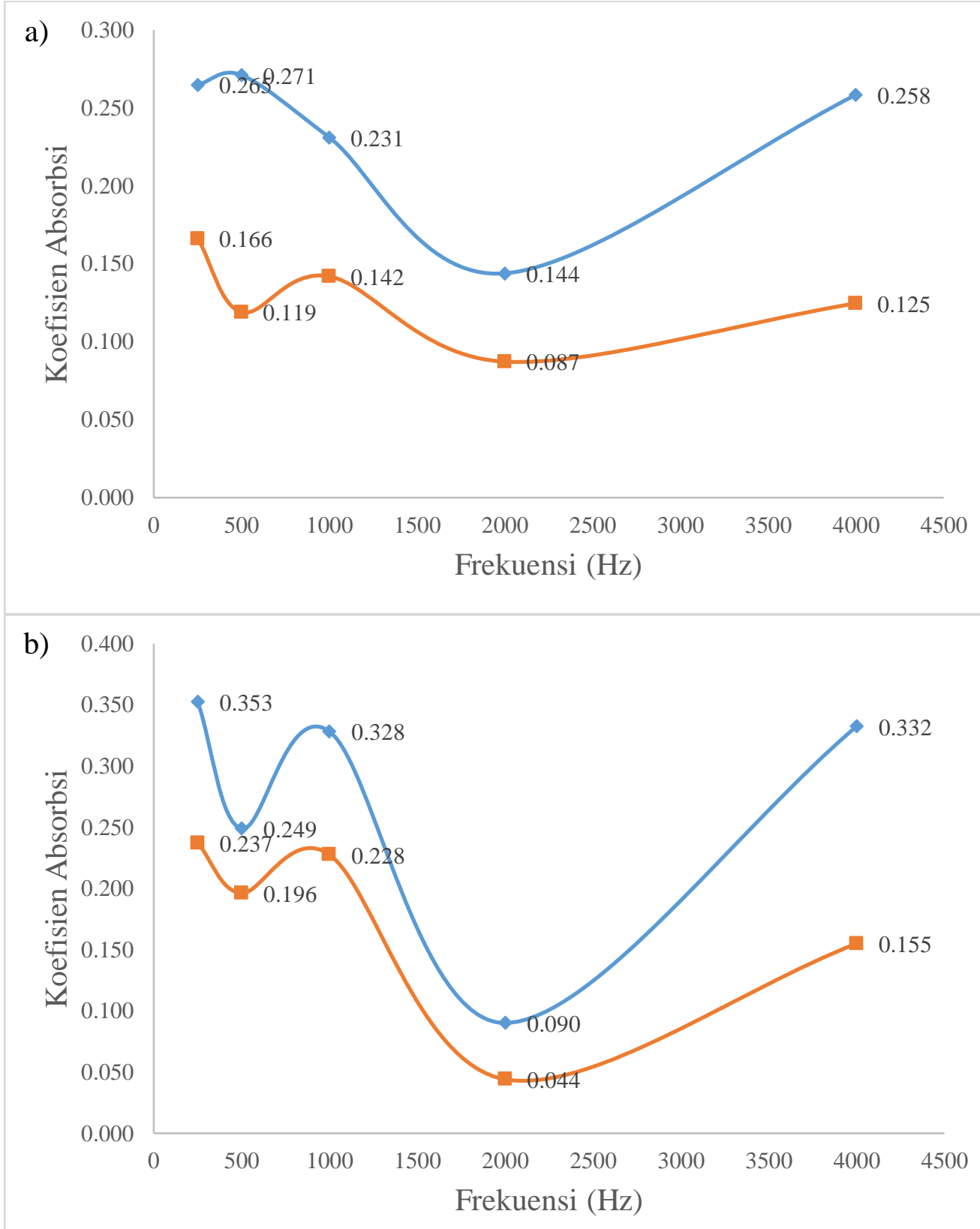

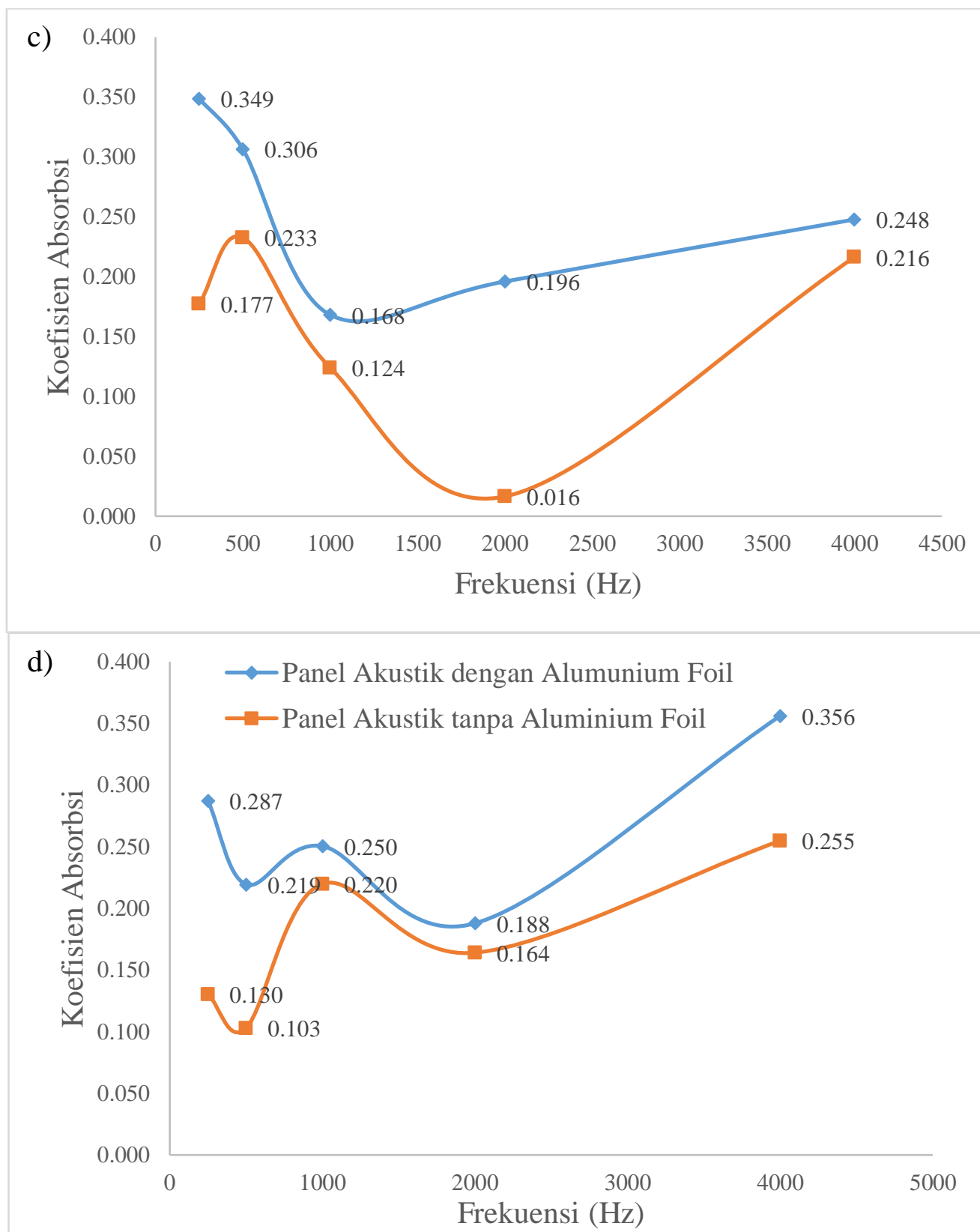

Gambar 2. Koefisien absorbsi panel akustik biji kapuk randu pada a) Jarak $10 \mathrm{~cm}$; b) jarak $20 \mathrm{~cm}$; c) jarak $30 \mathrm{~cm}$; dan jarak $40 \mathrm{~cm}$ dari sumber suara dengan berbagai frekuensi

Gambar 2 juga memperlihatkan bahwa dengan penambahan aluminium foil dapat digunakan untuk mengurangi tingkat kebisingan bunyi dimana koefisien absorbsi tertingi sebesar 0,35 dengan frekuensi $4000 \mathrm{~Hz}$ untuk panel akustik biji dan kulit kapuk randu dengan aluminium foil. Sedangkan panel akustik tanpa aluminium foil koefisien absropsi tertinggi sebesar 0,255 pada frekuensi $4000 \mathrm{~Hz}$ dan berada padaJarak $40 \mathrm{~cm}$ dari sumber suara. Dengan demikian dapat dikatakan penyerapan bunyi paling efektif pada jarak 40 $\mathrm{cm}$ berada pada frekuensi $4000 \mathrm{~Hz}$.

Penggunaan material kulit kapuk randu ini bertujuan untuk mengetahui karakteristik penjalaran gelombang dan pengaruh dari jenis material material pada material yang berbeda. Berdasarkan Gambar 3, fenomena penjalaran gelombang pada medium padat mempunyai karakteristik koefisien absorbsi yang berbeda. Pada Gambar 2 
memperlihatkan optimalnya penyerapan material berada pada jarak $40 \mathrm{~cm}$ dengan frekuensi $4000 \mathrm{~Hz}$, sedangkan pada kulit kapuk randu (Gambar 3), koefisien absorbsi optimal berada pada jarak $30 \mathrm{~cm}$ berada pada frekuensi $2000 \mathrm{~Hz}$ dengan koefisien absorbsi secara berurutan sebesar 0,435 dan 0,351 pada panel akustik kulit kapuk randu dengan aluminium foil dan tanpa aluminium foil. Dari Gambar 3 juga memperlihatkan penambahan aluminium foil dapat meningkatkan koefisien absorbsi panel akustik dari kulit, biji halus dan kasar kapuk randu.
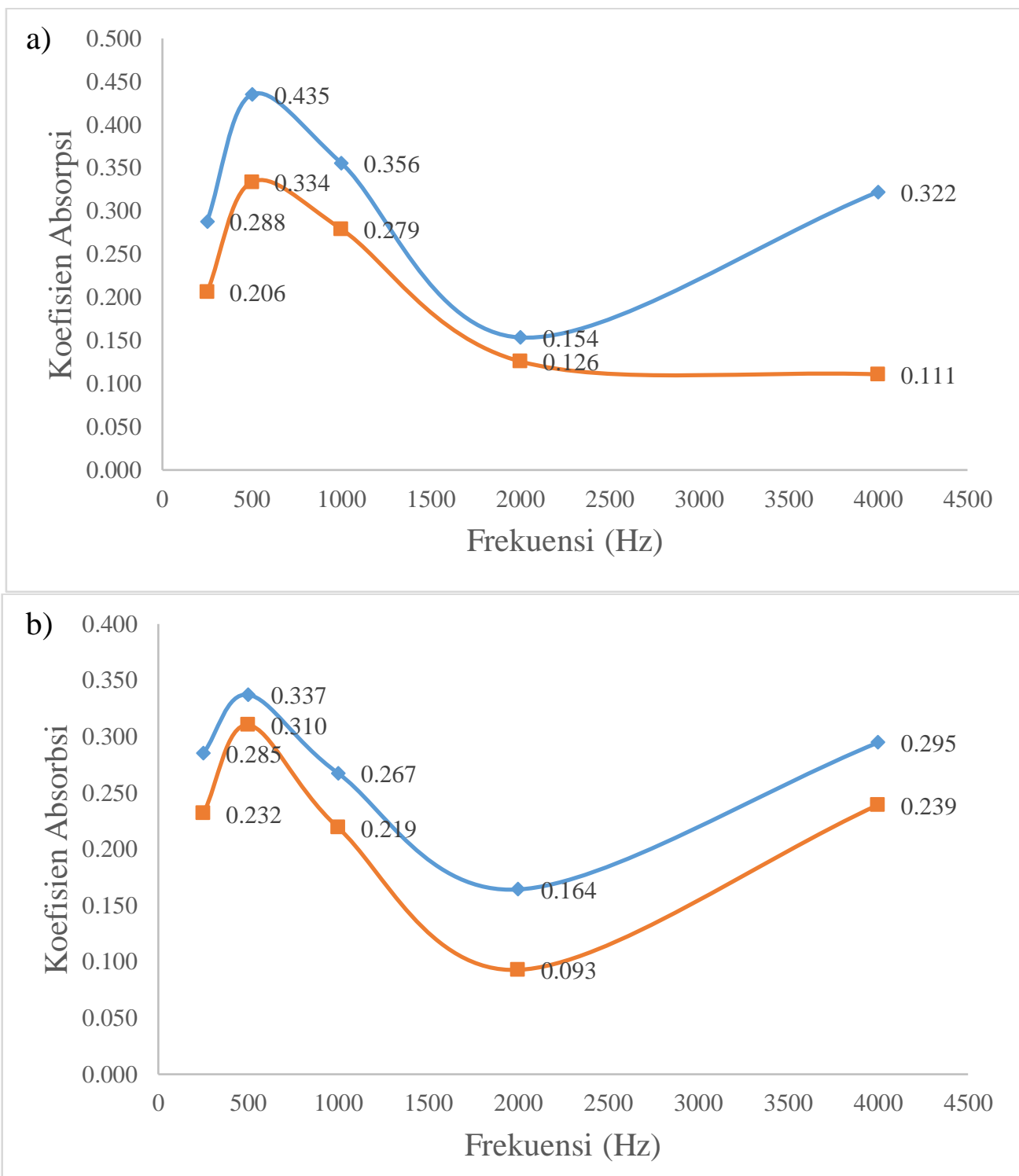


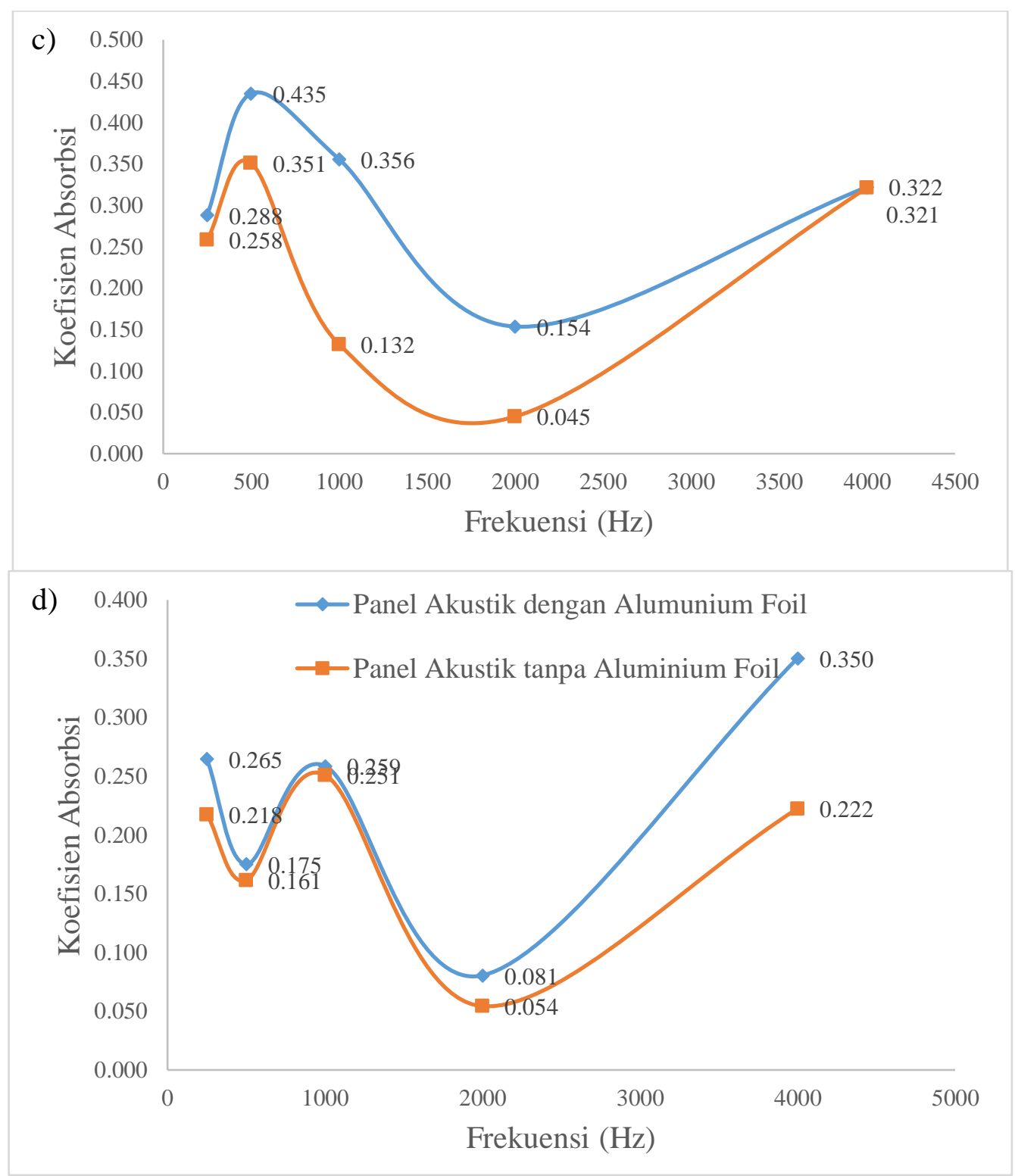

Gambar 3. Koefisien absorbsi panel akustik kulit kapuk randu pada a) Jarak $10 \mathrm{~cm}$; b) jarak $20 \mathrm{~cm}$; c) jarak $30 \mathrm{~cm}$; dan d) jarak $40 \mathrm{~cm}$ dari sumber suara dengan berbagai frekuensi

Gambar 2 maupun Gambar 3 memperlihatkan jarak dapat memengaruhi koefisien absorbsi panel akustik. Untuk panel akustik biji kapuk randu tanpa aluminium foil koefisien absorbsi terendah sebesar 0,016 berada pada jarak $30 \mathrm{~cm}$ dengan frekuensi 2000 Hz. Selanjutnya untuk memahami karakteristik material dan penyerapan gelombang, panel akustik biji halus kapuk randu dilakukan dimana hasil pengujiannya ditunjukan pada Gambar 4. 

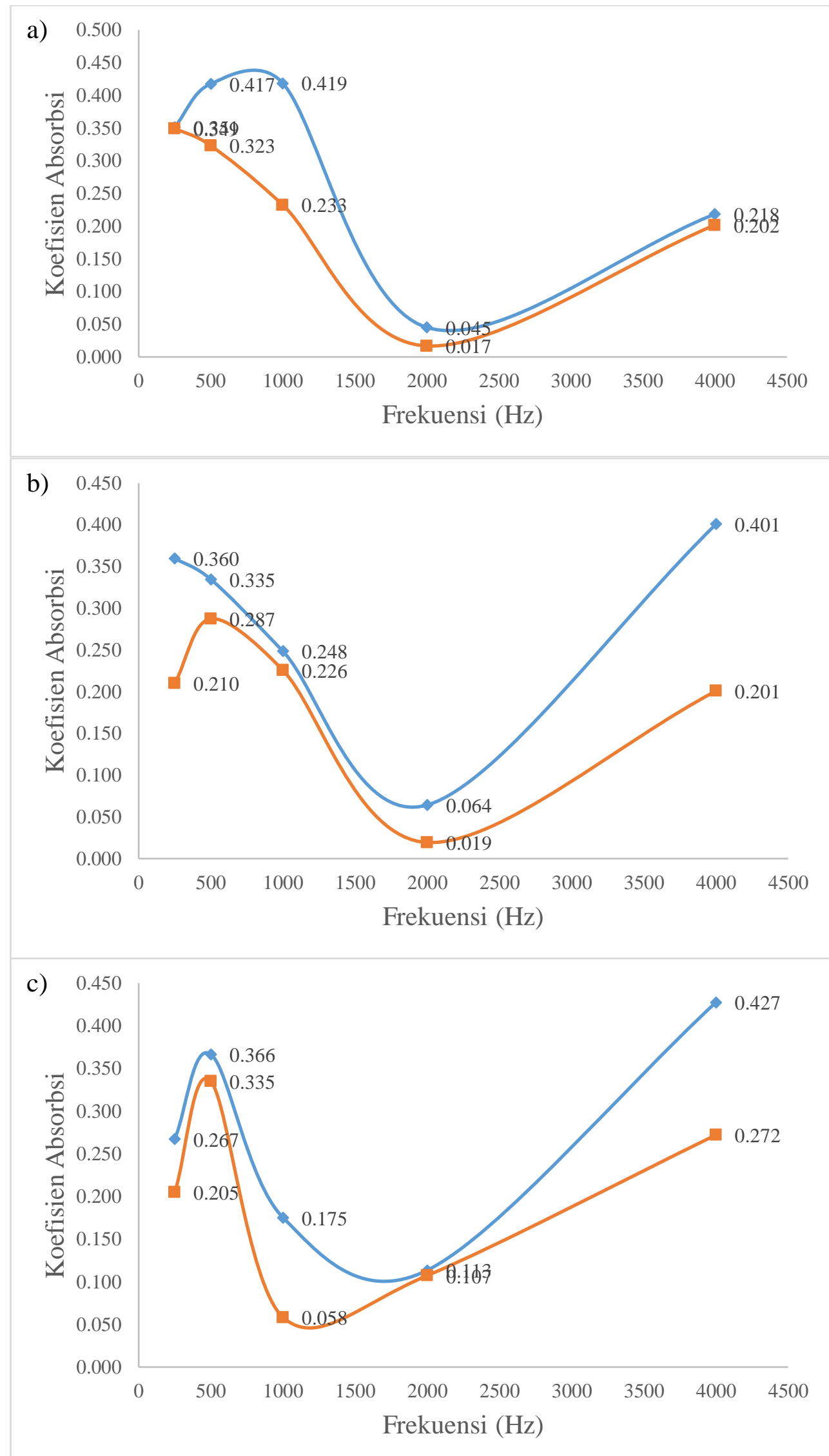


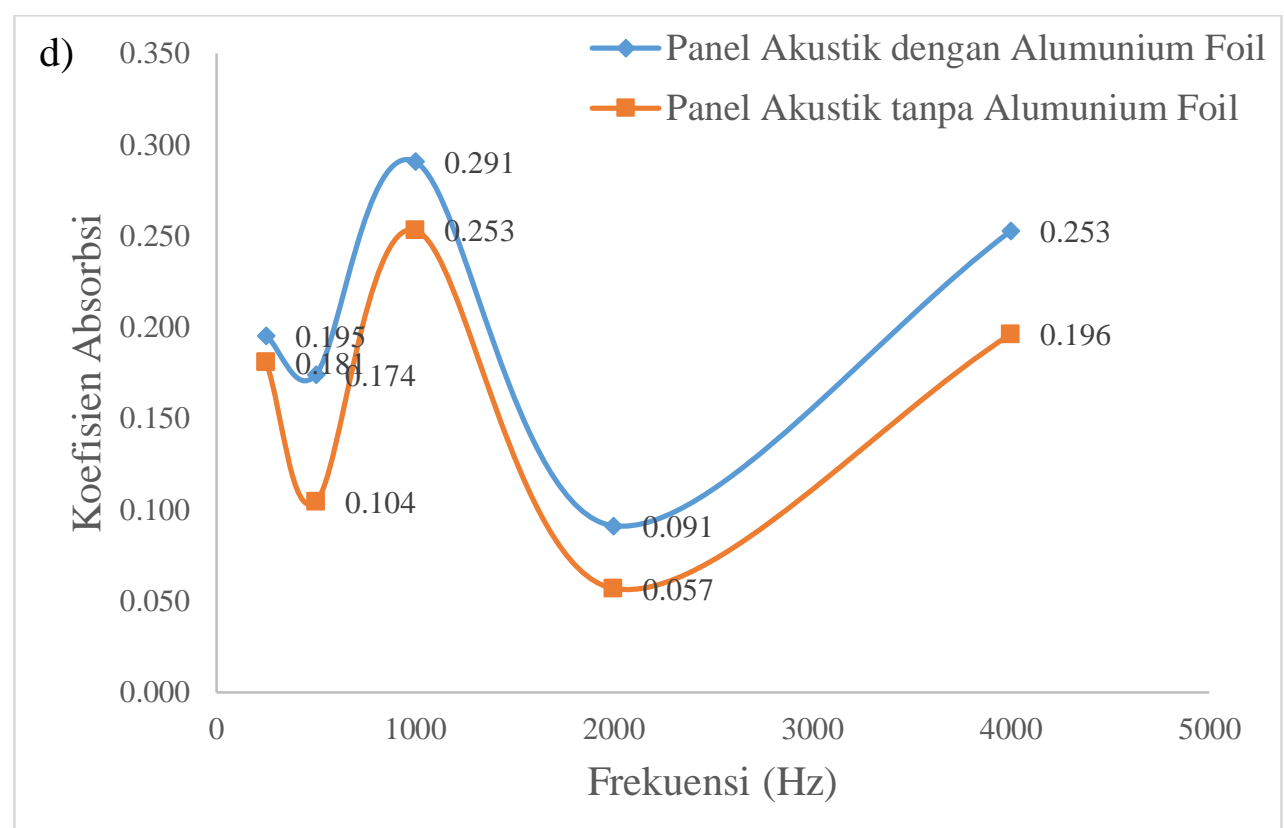

Gambar 4. Koefisien absorbsi panel akustik biji halus kapuk randu pada a) Jarak $10 \mathrm{~cm}$; b) jarak $20 \mathrm{~cm}$; c) jarak $30 \mathrm{~cm}$; dan d) jarak $40 \mathrm{~cm}$ dari sumber bunyi dengan berbagai frekuensi

Gambar 4 menunjukan bahwa penambahan aluminium foil pada panel akustik biji kapuk dihaluskan dapat meningkatkan koefisien absorbsi, dan koefisien absorbsi optimal sebesar 0,427 dengan frekuensi sebesar $2000 \mathrm{~Hz}$ dan jarak $30 \mathrm{~cm}$ dari sumber bunyi pada panel akustik biji kapuk halus dengan aluminium foil, sedangkan koefisien absorbsi optimal tanpa aluminium foil sebesar 0,335 pada frekuensi $500 \mathrm{~Hz}$ dengan jarak $30 \mathrm{~cm}$ dari sumber bunyi. Berdasarkan hasil pengamatan diatas, bahan alam dapat digunakan sebagai bahan peredaman geombang bunyi sehingga dapat digunakan sebagai pengganti bahan sintetik yang tidak ramah lingkungan. Hal yang sama juga telah dilakukan oleh Sekar et al. (2019) dalam mendeskripsikan bahan alam sebagai bahan peredam gelombang bunyi, diantaranya serat pisang, serat rami, daun tea, dan bamboo. Selain itu, rasio matriks (resin polyester) dengan pengurat (biji kapuk randu), dan densitas panel akustik dapat mempengaruhi koefisien absorpsi (Liu et al., 2015).

Berdasarkan pengamatan dari ketiga jenis panel akustik biji, kulit, dan biji halus kapuk randu menunjukan bahwa karakteristik penyerapan gelombang berbeda sehingga menghasilkan koefisien absorpsi yang berbeda. Selain itu, penambahan alumunium foil dapat meningkatkan koefiesien absorbsi dari panel akustik tersebut, dan dan jarak sumber bunyi dengan sampel panel akustik juga dapat mempengaruhi koefisien absorpsi.

\section{KESIMPULAN}

Pengembangan panel akustik telah dilakukan dari penelitian ini dengan cara memanfaatkan material yang ringan, ramah lingkungan, dan dapat dibudidayakan, seperti biji dan kulit kapuk randu. Selain itu, pengembangan dilakukan dengan cara menambahkan aluminium foil pada panel akustik. Adapun simpulan dari pengembangan panel akustik yaitu: Penambahan aluminium foil pada panel akustik biji kapuk dihaluskan dapat meningkatkan koefisien absorbsi, dan koefisien absorbsi optimal sebesar 0,427 dengan frekuensi sebesar $2000 \mathrm{~Hz}$ dan jarak $30 \mathrm{~cm}$ dari sumber bunyi pada panel akustik biji kapuk halus dengan aluminium foil, sedangkan koefisien absorbsi optimal tanpa aluminium foil sebesar 0,335 pada frekuensi $500 \mathrm{~Hz}$ dengan jarak $30 \mathrm{~cm}$ dari sumber 
bunyi; Koefisien absorbsi optimal pada kulit kapuk randu berada pada jarak $30 \mathrm{~cm}$ berada pada frekuensi $2000 \mathrm{~Hz}$ dengan koefisien absorbsi secara berurutan sebesar 0,435 dan 0,351 pada panel akustik kulit kapuk randu dengan aluminium foil dan tanpa aluminium foil dan; Penambahan aluminium foil dapat digunakan untuk mengurangi tingkat kebisingan bunyi dimana koefisien absorbsi tertinggi sebesar 0,35 dengan frekuensi 4000 $\mathrm{Hz}$ untuk panel akustik biji dan kulit kapuk randu dengan aluminium foil. Sedangkan panel akustik tanpa aluminium foil koefisien absropsi tertinggi sebesar 0,255 pada frekuensi $4000 \mathrm{~Hz}$ dan berada pada Jarak $40 \mathrm{~cm}$ dari sumber suara. Dengan demikian dapat dikatakan penyerapan bunyi paling efektif pada jarak $40 \mathrm{~cm}$ berada pada frekuensi $4000 \mathrm{~Hz}$.

\section{DAFTAR PUSTAKA}

Ali, W.W.M., Ooi, L.E., \& Ishak, Z.A.M. (2018). Sound and Vibration Damping Properties of Nonwoven Flax Reinforced Acrylic Based Polyester Composites. MATEC Web.of Conferences, 217(01007), 18. doi: https://doi.org/10.1051/matecconf/201821701007.

Aluko, E., \& Nna, V. (2015). Impact of Noise Pollution on Human Cardiovascular System. International Journal of Tropical Disease \& Health, 6(2), 35-43. doi: https://doi.org/10.9734/ijtdh/2015/13791.

Kumar, R., Hynes, N.R.J., Senthamaraikannan, P., Saravanakumar, S., \& Sanjay, M.R. (2018). Physicochemical and Thermal Properties of Ceiba pentandra Bark Fiber. Journal of Natural Fibers, 15(6), 822-829. doi: https://doi.org/10.1080/15440478.2017.1369208.

Kusmiran, A., Hidayat, M., Desiasni, R., \& Maad, A.Z. (2019). Numerical analysis of Composite with Natural Fiber Reinforcement using Finite Element Method: Leaf Spring Composite Application. ICOST 2019. doi: 10.4108/eai.2-5-2019.2284617.

Kusmiran, A., Suwandi, N., Desiasni, R. (2020). Analisis Pengaruh Konsentrasi Natrium Hidroksida terhadap Sifat Mekanik Biokomposit Berpenguat Serat Sisal. Jurnal Fisika, 10 (2), 11-18. doi: https://doi.org/10.15294/jf.v10i2.25462.

Liu, X., Yan., X., Li, L., \& Zang, H. (2015). Sound Absorption Properties of Kapuk Fiber Nonwoven Fabrics at Low Frequency. Journal of Natural Fibers, 12, 311-322. doi: 10.1080/15440478.2014.919891.

Münzel, T., Gori, T., Babisch, W., \& Basner, M. (2014). Cardiovascular effects of environmental noise exposure. European Heart Journal, 35(13), 829-836. doi: https://doi.org/10.1093/eurheartj/ehu030.

Purnawati, R., Febrianto, F., Wistara, I.N.J., Nikmatin, S., Hidayat, W., Lee, S. H., \& Kim, N. H. (2018). Physical and chemical properties of kapok (Ceiba pentandra) and balsa (Ochroma pyramidale) fibers. Journal of the Korean Wood Science and Technology, 46(4), 393-401. doi: https://doi.org/10.5658/WOOD.2018.46.4.393.

Sekar, V., Fouladi, M.H., Namasivayam, S.N., \& Sivanesan, S. (2019). Additive Manufacturing: A Novel Method for Developing an Acoustic Panel Made of Natural Fiber-Reinforced Composites with Enhanced Mechanical and Acoustical Properties. Journal of Engineering (United Kingdom). 2019, 1-19. doi: https://doi.org/10.1155/2019/4546863.

Thuault, A., Bazin, J., Eve, S., Bréard, J., \& Gomina, M. (2014). Numerical study of the influence of structural and mechanical parameters on the tensile mechanical behaviour of flax fibres. Journal of Industrial Textiles, 44(1), 22-39. doi: https://doi.org/10.1177/1528083713481835.

Xiang, H. F., Wang, D., Liua, H. C., Zhao, N., \& Xu, J. (2013). Investigation on sound absorption properties of kapok fibers. Chinese Journal of Polymer Science (English Edition), 31(3), 521-529. doi: https://doi.org/10.1007/s10118-013-1241-8.

Yahya, M. N., Sambu, M., Latif, H. A., \& Junaid, T. M. (2017). A study of Acoustics Performance on Natural Fibre Composite. IOP Conference Series: Materials Science and Engineering, 226(1). doi: https://doi.org/10.1088/1757-899X/226/1/012013. 